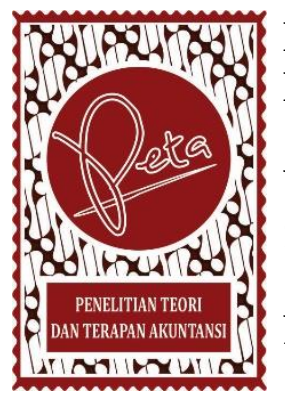

\title{
PERLAKUAN AKUNTANSI ASET TETAP TERHADAP
} LAPORAN KEUANGAN BERDASARKAN SAK ETAP

\author{
Yensia Prarisma Nur Sahara ${ }^{1}$
}

Sulistya Dewi Wahyuningsih ${ }^{2}$

${ }^{12}$ Sekolah Tinggi Ilmu Ekonomi Kesuma Negara Blitar, J1.

Mastrip No. 59, Kepanjen Kidul Blitar

Surel:dewi@stieken.ac.id

\begin{abstract}
Abstrak. Perlakuan Akuntansi Aset Tetap terhadap Laporan Keuangan Berdasarkan SAKETAP.Tujuan penelitian ini adalah mengetahui perlakuan akuntansi aset tetap pada penyajian laporan keuangan yang didasarkan pada SAK ETAP. Penulis menggunakan sampel seluruh data aset tetap dan laporan keuangan pada Hotel Blitar Indah periode 2014-2016. Hasil penelitian menunjukkan bahwa perlakuan akuntansi aset tetap pada Hotel Blitar Indah belum sepenuhnya sesuai dengan SAK ETAP. Perhitungan perolehan aset tetap sudah sesuai SAK ETAP, namun belum dilakukan perhitungan penyusutan dan penghentian aset tetap. Hal tersebut menyebabkan laba yang disajikan pada Laporan Laba Rugi pihak hotel lebih besar daripada laba yang disajikan pada Laporan Laba Rugi setelah perhitungan penyusutan sesuai SAK ETAP dengan menggunakan Metode Garis Lurus. Aset tetap yang disajikan pada Neraca hotel, nilainya juga lebih besar. Berdasarkan hasil penelitian dapat disimpulkan bahwa perlakuan akuntansi aset tetap harus didasarkan pada SAK ETAP guna menyajikan laporan keuangan yang akurat sehingga dapat dijadikan sebagai salah satu dasar pengambilan keputusan di masa yang akan datang.
\end{abstract}

Kata Kunci:Perlakuan Akuntansi AsetTetap, Laporan Keuangan, SAK ETAP

Abstract. Accounting Practice of Fixed Asset to Financial Statement Under Indonesian GAAP. The purpose of this study is to know the accounting practice of fixed assets in the presentation of financial statements based on SAK ETAP. The author uses the sample of all data of fixed assets and financial statements at the Blitar Indah Hotel period 2014-2016. The results showed that the accounting practice of fixed assets at Blitar Indah Hotel has not been fully in accordance with SAK ETAP. The calculation of the acquisition of property, plant and equipment is in accordance with SAK ETAP, but no depreciation and fixed asset account has been calculated yet. This results in the profit presented in the hotel's Income Statement is greater than the profit presented in the Income Statement after the depreciation calculation in accordance with ETAP SAK by using the Straight-line Method. Fixed assets that are presented in the hotel's balance sheet, the value is also greater. Based on the results of the study can be concluded that the accounting treatment of fixed assets should be based on SAK ETAP in order to present accurate financial statements that can be used as one of the basic decisionmaking in the future. 
Keywords: Fixed Asset Accounting Treatment, Financial Statement, SAK ETAP

\section{PENDAHULUAN}

Dunia bisnis yang semakin berkembang, menuntut para pengusaha untuk semakin pandai dalam bersaing guna mempertahankan kelangsungan hidup perusahaan. Oleh karena itu, pengusaha harus mampu menekan pengeluaran dan memperbesar pemasukan guna memperoleh laba maksimal. Tidak hanya mengontrol pada pemasukan dan pengeluaran secara fisik saja, pengusaha juga harus memastikan bahwa perhitungan dan pencatatan transaksi yang dilakukan sudah sesuai Standar Akuntansi Keuangan agar laba yang dihasilkan pada laporan keuangan sesuai dengan kondisi yang ada. Laporan keuangan harus disajikan secara tepat dan akuratkarena laporan keuangan akan digunakan sebagai salah satu bahan pertimbangan untuk pengambilan keputusan dimasa yang akan datang.

Hotel Blitar Indah merupakan hotel milik perorangan yang ditetapkan sebagai Hotel kelas Melati. Hotel Blitar Indahmenyediakan fasilitas sesuai dengan kelas kamar yang dipilih oleh pelanggan, mulai dari peralatan kamar tidur, kamar mandi dan makanan yang diperoleh. Aset tetap merupakan harta perusahaan yang memiliki masa manfaat diatas satu tahun, digunakan untuk kegiatan operasional perusahaan dan tidak untuk diperjualbelikan.

Pada bisnis di bidang perhotelan, aset tetap merupakan bagian terpenting, mulai dari bangunan sampai peralatan yang ada di hotel harus menumbuhkan rasa nyaman pada pelanggan guna menarik para wisatawan sehingga perlu dilakukan pengelolaan yang baik pada aset tetap, baik secara fisik dengan melakukan perawatan, dan pengelolaan pada perhitungan dan pencatatannya. Pencataan yang dilakukan pada saat perolehan aset tetap, penyusutan aset tetap dan pelepasan aset tetap harus dilakukan sesuai standar akuntansi keuangan guna menggambarkan kondisi aset tetap yang sebenarnya.

Pada saat perolehan aset tetap pencatatan harus dilakukan sesuai dengan biaya yang dikeluarkan seperti harga aset tetap, biaya angkut dan biaya tambahan lainnya. Setelah dilakukan pemakaian tentunya aset mengalami penurunan manfaat sehingga harus dilakukan perhitungan penyusutan, selanjutnya dilakukan perhitungan dan pencatatan pada saat melakukan pelepasan aset tetap. Berdasarkan latar belakang di atas, penulis melakukan penelitian dengan judul "Perlakuan Akuntansi Aset Tetap Terhadap Laporan Keuangan Berdasarkan SAK ETAP".

\section{Permasalahan}

Pada aset tetap di Hotel Blitar Indah, hanya dilakukan pencatatan pada saat perolehan, tanpa melakukan perhitungan penyusutan dan penghentian aset tetap. Selama ini bagian 
administrasi hanya melakukan pencatatan pada saat pembelian aset tetap dan setelah 5 tahun digunakan untuk kegiatan operasional perusahaan, aset tetap akan dihentikan penggunaannya dengan cara memberikannya pada karyawan tanpa adanya perhitungan dan pencatatan pada pelepasan aset tetap.

Berdasarkan jenis pelepasan aset tetap, Hotel Blitar Indah seharusnya menggunakan metode penghentian aset tetap karena aset tetap hanya dihentikan penggunaannya tanpa ditukar ataupun dijual. Tidak adanya perhitungan dan pencatatan pada penyusutan akan mempengaruhi nilai aset tetap pada saat dilakukan penghentian, karena nilai aset tetap yang tertulis pada laporan keuangan tidak sesuai dengan nilai aset tetap yang sesungguhnya pada periode yang berjalan. Sementara penghentian aset tetap dihitung berdasarkan penyusutan dan nilai akhir aset tetap, jika nilai aset tetap pada laporan aset tetap tidak sesuai dengan nilai aset tetap yang sesungguhnya penghentian aset tetap tidak akurat. Sehingga perhitungan dan pencatatan aset tetap mulai dari perolehan, penyusutan dan penghentian harus dilakukan sesuai Standar Akuntansi Keuangan.

Perhitungan dan pencatatan yang tidak sesuai Standar Akuntansi Keuangan akan berpengaruh pada laporan keuangan terutama pada neraca, laporan rugi laba dan perubahan ekuitas. Pada neraca, penghentian aset tetap akan mempengaruhi nilai aset tetap; pada laba rugi akan

mempengaruhi nilai beban pada periode berjalan dan pada laporan perubahan modal akan mempengaruhi jumlah laba yang berasal dari laporan laba rugi. Oleh karena itu, untuk mencapai hasil keuangan yang tepat dan akurat, perlu dilakukan pembenahan perhitungan dan pencatatan aset tetap sesuai SAK ETAP Bab 15.

Berdasarkan permasalahan yang dijelaskan diatas, maka rumusan masalah yang didapat penulis adalah bagaimana perlakuan akuntansi aset tetap terhadap laporan keuangan berdasarkan SAK ETAP pada Hotel Blitar Indah?Berdasarkan permasalahan diatas, maka penelitian ini bertujuan untuk mengetahui perlakuan akuntansi aset tetap terhadap laporan keuangan berdasarkan SAK ETAP pada Hotel Blitar Indah.

\section{TELAAH LITERATUR}

\section{Penelitian Terdahulu}

Dalam

penelitian menggunakan terdahulu sebagai bahan referensi. Berikut daftar penelitian terdahulu:

1. Eko Noviana Wulansari (2013), melakukan penelitian dengan judul "Penerapan Akuntansi Aktiva Tetap Pada Rumah Bersalin An-Nisaa' Wlingi", dengan variabel aktiva tetap.

Berdasarkan penelitian ini penulis dapat menyimpulkan bahwa pengelompokan aktiva tetap pada Rumah Bersalin AnNisaa' Wlingi berdasarkan tahun perolehan dan fungsi aktiva tetap. Perolehan aktiva tetap dengan cara pembelian 
tunai, angsuran dan membangun sendiri kemudian melakukan pencatatan pada laporan keuangan yang telah sesuai Standar Akuntansi Keuangan. Metode Penyusutan yang dipilih adalah Metode Garis Lurus karena dinilai lebih menghasilkan laba yang maksimal.

2. Yuyus Kristiana (2014), melakukan penelitian dengan judul "Analisis Perlakuan Akuntansi Aset Tetap Berwujud dan Penerapan Metode Depresiasi Untuk Pengungkapan Laporan Keuangan Pada CV. Tirtonadi Blitar".

Variabel yang digunakan adalah aset tetap berwujud, depresiasi, dan laporan keuangan.

Berdasarkan penelitian ini, penulis dapat menyimpulkan bahwa CV.Tirtonadi melakukan perhitungan dan pencatatan harga perolehan aset tetap dan metode depresiasi aset tetap belum sesuai dengan PSAK16. Perhitungan harga perolehan aset tetap hanya berdasarkan harga beli aset tetap ditambah dengan PPN tanpa menghitung biaya lain-lain yang seharusnya dihitung sebagai harga perolehan aset tetap. Hal ini mengakibatkan perhitungan penyusutan aset tetap belum akurat karena perhitungan penyusutan aset tetap didasarkan pada harga perolehan, sehingga penyajian aset tetap pada laporan keuangan belum menggambarkan keadaan sebenarnya.
3. Tri Yanti Wana Wijaya et.al. (2014), melakukan penelitian dengan judul "Analisis Perlakuan Akuntansi Atas Aset Tetap Terhadap Laporan Keuangan berdasarkan SAK ETAP no.15 (Studi Kasus Pada PT. BP Delta Singosari)"

Variabel yang digunakan adalah perlakuan akuntansi, aset tetap, dan laporan keuangan.

Kesimpulan yang didapat, bahwa perlakuan akuntansi aset tetap pada PT. BPR Delta Singosari belum sesuai dengan SAK ETAP. Pada PT. BPR Delta Singosari, perolehan aset tetap sudah dicatat sesuai dengan SAK ETAP tetapi pada penyusutan aset tetap dengan menggunakan metode garis lurus tidak mengakui adanya tanah dan bangunan pada laporan keuangan dan masih melakukan pencatatan aset tetap yang telah habis masa manfaatnya pada laporan keuangan.

\section{Pengertian Aset Tetap}

Menurut Jusup (2011:133), “Aset Tetap adalah sumber daya yang memiliki empat karakteristik yaitu : (1) berujud atau memiliki ujud (bentuk atau ukuran tertentu), (2) digunakan dlam operasi perusahaan, (3) mempunyai manfaat jangka panjang dan (4) tidak dimaksudkan untuk diperjualbelikan".

\section{Jenis-Jenis Aset Tetap}

Menurut Reeve et.al. (2014:2), "Perusahaan membeli dan menggunakan berbagai aset tetap 
seperti peralatan, perabotan, alatalat, mesin, gedung dan tanah".

\section{Perolehan Aset Tetap}

Menurut Baridwan (2008:278), aset tetap dapat diperoleh dengan berbagai cara berikut:

1. Pembelian Tunai

2. Pembelian Secara Gabungan

3. Perolehan melalui pertukaran ada dua macam yaitu :

a. Pertukaran dengan suratsurat berharga berupa saham atau obligasi perusahaan akan dicatat dalam rekening modal sahatm atau utang obligasi sebesar nilai nominal, selisih nilai pertukaran dengan nilai nominal dicatat dalam rekening agio/disagio.

b. Pertukaran dengan aset tetap yang lain dapat dilakukan dengandua cara yaitu pertukaran dengan aset tetap sejenis dan pertukaran dengan aset tetap tidak sejenis.

4. Pembelian Angsuran, pada pembelian angsuran harga perolehan aset tetap bunga angsuran dibebankan sebagai biaya bunga dan harus dikeluarkan dari harga perolehan.

5. Diperoleh dari Hadiah atau Donasi pencatatan bisa dilakukan menyimpang dari prinsip harga perolehan.

6. Aset Tetap yang dibuat sendiri harga perolehan ditentukan dengan membebankan langsung semua biaya yang dikeluarkan pada saat membangun aset tetap.
Pengakuan Aset Tetap

Menurut SAK ETAP Bab 15 (2009:68) "Entitas harus menerapkan kriteria pengakuan dalam menentukan pengakuan aset tetap. Oleh karena itu, entitas harus mengakui biaya perolehan aset tetap sebagai aset tetap jika: (a) kemungkinan bahwa manfaat ekonomi yang terkait dengan pos tersebut akan mengalir dari atau ke dalam entitas; dan(b) pos tersebut mempunyai nilai atau biaya yang dapat diukur dengan andal".

\section{Pengukuran Awal Aset Tetap}

Menurut SAK ETAP Bab 15 (2009:68) "Pada saat pengakuan awal aset tetap harus diukur sebesar biaya perolehan".

\section{Harga Perolehan Aset Tetap}

Menurut Greuning et.al. (2013:128), "Harga Perolehan adalah jumlah kas atau setara kas yang dibayarkan dan nilai wajar dari apapun yang diserahkan untuk memperoleh aset tersebut pada waktu penyerahan atau konstruksi".

\section{Pengeluaran Setelah Pengakuan} Awal

Menurut Baridwan (2008:289) "Pengeluaran yang digunakan dengan tujuan memenuhi kebutuhan aset tetap yang diharapkan memenuhi tujuan perusahaan dapat dilakukan sebagai berikut:

a. Reparasi dan Pemeliharaan merupakan biaya yang dikeluarkan untuk pemeliharaan aset tetap baik dalam jumlah besar maupun kecil. 
b. Penggantian merupakan biaya yang dikeluarkan untuk mengganti bagian dari aset tetap dengan unit baru dengan tipe sejenis.

c. Perbaikan merupakan biaya merupakan biaya penggantian aset tetap dengan tujuan memperoleh kegunaan yang lebih besar.

d. Penambahan merupakan biaya yang dikeluarkan untuk memperbesar atau memperluas fasilitas aset tetap.

e. Penyusunan Kembali Aset Tetap merupakan biaya yang dikeluarkan untuk penyusunan kembali aset tetap".

Penyusutan Aset Tetap dan Metode Penyusutan Aset Tetap

Menurut Jusup (2011:144), "Depresiasi adalah proses pengalokasian biaya perolehan aset tetap menjadi beban selama masa manfaatnya dengan cara yang rasional dan sistematis".

Menurut SAK ETAP Bab 15 (2009:73), "Suatu entitas harus memilih metode penyusutan yang mencerminkan ekspektasi dalam pola penggunaan manfaat ekonomi masa depan aset. Beberapa metode penyusutan yang mungkin dipilih, antara lain metode garis lurus (straight line method), metode saldo menurun (diminishingbalance method), dan metode jumlah unit produksi (sum ofthe unit of production method)".

\section{Pelepasan Aset Tetap dan Metode Pelepasan Aset Tetap}

Menurut Martani et.al. (2012:287), "Jumlah tercatat aset tetap dihentikan pengakuannya pada saat dilepaskan atau tidak ada manfaat ekonomis masa depan yang diharapkan dari penggunaan atau pelepasannya".

Menurut Jusup (2009:162), "Pada saat pelepasan terjadi, perusahaan harus mencatat penyusutan dan kemudian menghapus nilai buku aset tetap melalui metode-metode: penghentian pemakaian aset tetap, penjualan aset tetap, dan pertukaran.

\section{Pengertian Laporan Keuangan}

Menurut Reeve et.al. (2010:315), "Laporan Keuangan dasar memberikan banyak informasi yang dapat dipakai oleh para pengguna dalam membuat keputusan ekonomis mengenai perusahaan".

\section{Jenis - Jenis Laporan Keuangan}

Menurut SAK ETAP Bab 3 (2009:17), "Laporan keuangan entitas meliputi: (a) neraca; (b) laporan laba rugi; (c) laporan perubahan ekuitas; (d) laporan arus kas; dan (e) catatan atas laporan keuangan".

\section{Pengertian SAK ETAP}

Menurut Bahri (2016:8), "SAK untuk entitas tanpa akuntabilitas publik digunakan untuk entitas yang tidak memiliki akuntabilitas publik yang signifikan dan menerbitkan laporan keuangan untuk tujuan umum bagi pengguna eksternal".

\section{METODE PENELITIAN Waktu dan Tempat Penelitian}

Penelitian ini dimulai dari November 2016 sampai dengan Maret 2017 agar mencapai hasil 
yang tepat dan akurat. Tempat penelitian yang dipilih oleh penulis adalah Hotel Blitar Indah yang beralamatkan di Jalan Jend. Ahmad Yani nomor 62 Kota Blitar.

\section{Jenis Penelitian}

Penelitian ini termasuk jenis penelitian deskriptif kuantitatif karena penelitian ini membahas dan mengungkapkan masalah dengan menggambarkan keadaan atau kondisi yang terjadi pada saat penelitian berlangsung kemudian melakukan analisa mengenai perlakuan akuntansi aset tetap dan laporan keuangan yang sesuai dengan SAK ETAP sehingga menghasilkan data berupa angkaangka yang bisa dibandingkan dengan teori yang ada untuk mendapatkan simpulan dari permasalahan. Data-data yang diperoleh berupa data asset tetap dan laporan keuangan.

\section{Definisi Operasional Variabel}

1. Perlakuan Akuntansi Aset Tetap Perlakuan akuntansi aset tetap adalah perlakuan akuntansi yang dilakukan pada aset tetap mulai dari perolehan aset tetap, penyusutan aset tetap hingga pelepasan aset tetap. Perlakuan akuntansi aset tetap harus dilakukan dengan benar karena adanya keterkaitan. Perhitungan perolehan aset tetap harus tepat guna melakukan perhitungan pada penyusutan aset tetap. Sementara pelepasan aset tetap dihitung berdasarkan aset tetap setelah penyusutan.

2. Laporan Keuangan

Laporan Keuangan adalah
sumber informasi yang
dihasilkan oleh proses akuntansi
pada suatu periode yang
digunakan sebagai dasar
pengambilan keputusan dimasa
yang akan datang.

\section{Populasi dan Sampel Penelitian}

Penulis menggunakan populasi sebagai objek penelitian yaitu seluruh data aset tetap dan laporan keuangan pada Hotel Blitar Indah. Sedangkan sampel yang digunakan adalah seluruh data aset tetap dan laporan keuangan pada Hotel Blitar Indah periode 2014 sampai 2016.

\section{Metode Pengumpulan Data}

1. Jenis Data

Jenis data yang digunakan dalam penelitian ini adalah data primer. Penulis melakukan wawancara langsung terhadap objek penelitian untuk memperoleh data yang berupa data kualitatif yaitu sejarah perusahaan, struktur organisasi perusahaan dan gambaran umum perusahaan serta data kuantitatif berupa data mengenai aset tetap dan laporan keuangan pada Hotel Blitar Indah.

2. Teknik Pengumpulan Data

Teknik pengumpulan data adalah proses dimana penulis mengumpulkan data-data yang digunakan sebagai dasar penelitian. Teknik pengumpulan data yang digunakan dalam penelitian ini adalah sebagai berikut :

1. Observasi 
2. Wawancara

3. Dokumentasi

\section{Teknik Analisis Data}

Teknik analisis data merupakan proses pengolahan data yang telah diperoleh pada pengumpulan data baik data kuantitatif maupun data kualitatif sebagai data penunjang penelitian. Lagkah-langkah analisa data penelitian ini adalah sebagai berikut :

1. Mengumpulkan data aset tetap yang dimiliki oleh Hotel Blitar Indah.

2. Menganalisa perlakuan akuntansi aset tetap pada Hotel Blitar Indah.

3. Menganalisa Laporan Laba Rugi, Laporan Perubahan Ekuitas dan Neraca pada Hotel Blitar Indah periode 2014 2016.

4. Menganalisa perlakuan akuntansi aset tetap berdasarkan SAK ETAP.

5. Melakukan perhitungan dan penyajian Laporan Laba Rugi, Laporan Perubahan Ekuitas dan Neraca periode 2014 - 2016 dengan perlakuan akuntansi aset tetap berdasarkan SAK ETAP.

6. Mengevaluasi perlakuan akuntansi aset tetap terhadap penyusunan laporan keuangan berdasarkan SAK ETAP.

7. Menarik kesimpulan mengenai pengaruh perlakuan akuntansi aset tetap terhadap penyusunan laporan keuangan berdasarkan SAK ETAP pada Hotel Blitar Indah.

\section{ANALISIS DATA DAN PEMBAHASAN}

\section{Gambaran Umum Tempat Penelitian}

1. Sejarah Perusahaan

Hotel Blitar Indah merupakan perusahaan yang bergerak pada bidang jasa perhotelan sejak tahun 1981 yang didirikan oleh pendiri sekaligus pemilik hotel Blitar Indah adalah Bapak Giek Soegianto. Hotel ini semakin berkembang karena berada pada pusat kota Blitar tepatnya di Jalan Jend. A. Yani Kota Blitar. Mudahnya akses menuju tempat-tempat wisata maupun tempat yang ada di sekitar kota Blitar dan tarif sewa yang terjangkau menjadi alasan dipilihnya hotel Blitar Indah sebagai tempat beristirahat atau singgah.

Pada awal berdiri Hotel Blitar Indah memiliki 19 kamar dengan fasilitas yang masih sederhana seperti tempat tidur dan meja. Selain itu hotel ini juga menyediakan tempat parkir yang luas untuk kendaraan para pelanggan. Dari tahun ke tahun Hotel Blitar Indah semakin ramai dikunjungi para pelanggan sehingga pemilik berfikir untuk memperluas usaha. Pada tahun 1986 hotel ini mengadakan perluasan usaha dengan menambahkan 29 kamar sehingga total ada 48 kamar dengan fasilitas tambahan seperti televisi, AC dan kamar mandi. Selain menambah jumlah kamar, penambahan resto juga menjadi salah satu perluasan usaha. Pembangunan resto dilakukan dengan tujuan menyediakan makanan dan 
minuman bagi pelanggan agar tidak kesulitan keluar masuk hotel untuk mencari makanan dan minuman. Melihat tingginya minat pelanggan pada kamar dengan fasilitas AC, hotel yang sudah di tetapkan menjadi Hotel Melati oleh kantor wilayah pasiwisata Jawa Timur ini menambahkan 3 kamar dengan fasilitas televisi, AC dan kamar mandi pada tahun 2010. Kini, hotel tidak hanya dijadikan tempat istirahat para wisatawan saja namun juga dijadikan tempat istirahat para sopir kendaraan besar yang bekerja antar kota maupun antar provinsi. Berbeda dengan para wisatawan, rata - rata sopir kendaraan ini hanya menginap untuk satu malam. Sehingga untuk tahun - tahun berikutnya tentu akan dilakukan perluasan usaha kembali seiring dengan peningkatan kebutuhan pelanggan hotel Blitar Indah.

2. Lokasi Perusahaan

Hotel Blitar Indah beralamatkan di Jalan Jend. A. Yani nomor 62 Kota Blitar.

3. Aspek Legalitas
a. Akta Pendirian
Hotel Blitar Indah didirikan pada tahun 1981 dengan bentuk perusahaan perseorangan, yaitu dimiliki oleh Bapak Giek Soegianto. Dengan akta pendirian No. IV/016/23/81 atau 25-1- 1989 No. 10/1989.
b. Surat Ijin Usaha Perdagangan (SIUP)

Hotel Blitar Indah memiliki

Surat Ijin Usaha

Perdagangan (SIUP) dengan nomor

503/00132/410.211.1/SIUP/ 2015 sebagai Hotel Melati yang bergerak di bidang Jasa Penginapan.

4. Aspek Manajemen

a. Struktur Organisasi

1. Manager

Tugas seorang manager adalah Merencanakan dan melaksanakan kebijakan umum hotel berdasarkan pola umum kebijakan yang telah digariskan. Dan bertanggung jawab atas segala operasional hotel, tenaga kerja dan keuangan.

2. Assistant Manager

Tugas utama seorang assistan manager adalah sebagai wakil manajer yang bertugas menggantikan semua tanggungjawab dan wewenang manager apabila manager sedang berhalangan hadir.

3. Housekeeping

Tanggung jawab Housekeeping adalah mengkoordinasi tiga bagian dibawahnya yaitu room, cleaning dan loundry. Divisi ini termasuk bagian yang sangat penting karena kepuasan pelanggan berhubungan langsung dengan bagian ini, sehingga harus dilakukan koordinasi secara baik 
untuk mencapai tujuan utama yaitu kepuasan pelanggan.

a. Room

Tanggung jawab room adalah Mengecek ulang seluruh kamar untuk kesiapan check-in dan check out pelanggan hotel serta melaporkan jika ada barang pelanggan yang tertinggal.

b. Cleaning

Tanggung jawab dan wewenang bagian cleaning adalah menjaga kebersihan hotel terutama bagian luar kamar seperti ruang kantor, front office dan semua ruangan selain kamar hotel.

c. Loundry

Tanggung jawab laundry adalah menjaga kebersihan barang pelanggan yang di laundry.

4. Front office and Receptionist

Tanggung jawab dan wewenang Front office and Receptionist adalah menerima dan memproses pelanggan yang akan checkin dan check out dan koordinasi dengan room.

5. Security

Tanggung jawab bagian security adalah menjaga keamanan dan kenyamanan hotel.

b. Jumlah Karyawan
Hotel Blitar Indah memiliki 28 karyawan.

c. Jam Kerja

Pada bagian roomboy jam kerja 24 jam / satu hari penuh dengan sistem satu hari kerja satu hari libur. Untuk jam istirahat sift pagi jam 12.00-13.00 WIB. Untuk sift sore jam 18.30-19.30 WIB.

d. Jumlah Kamar Hotel Saat ini Hotel Blitar Indah memiliki 51 kamar hotel yang dibagi dalam tiga kelas sebagai berikut:

- Kamar Kelas VIP 8 unit

- Kamar Kelas Ekonomi 12 unit

- Kamar Kelas Standar 31 unit

\section{Analisis Data}

1. Aset Tetap pada Hotel Blitar Indah
a. Tanah
b. Bangunan
c. Peralatan

1) Peralatan Kamar Hotel terdiri dari:

- AC

- Televisi

- Meja Kamar

- Tempat Tidur

2) Peralatan Kantor terdiri dari:

- Meja Kursi Tamu

- Meja Receptionist

- Meja Kerja

- Kursi Kerja

- Kipas Angin

- Almari

- Telepon 
2. Perlakuan akuntansi aset tetap pada Hotel Blitar Indah

1) Perolehan Aset Tetap

2) Cara Perolehan Aset Tetap
Hotel Blitar Indah memperoleh aset tetap dengan pembelian tunai kecuali pada bangunan yang diperoleh dengan cara membangun sendiri.

3) Harga Perolehan Aset Tetap

Tabel 1. Harga Perolehan Aset Tetap

\begin{tabular}{|c|l|c|r|}
\hline NO & \multicolumn{1}{|c|}{$\begin{array}{c}\text { ASET } \\
\text { TETAP }\end{array}$} & JUMLAH & $\begin{array}{r}\text { HARGA } \\
\text { PEROLEHAN } \\
\text { (dalam rupiah) }\end{array}$ \\
\hline 1 & Tanah & $4.023 \mathrm{~m}^{2}$ & 3.903 .231 .000 \\
\hline 2 & Bangunan & $1.799 \mathrm{~m} 2$ & 1.464 .117 .000 \\
\hline 3 & $\begin{array}{l}\text { Air } \\
\text { Conditioner }\end{array}$ & 6 unit & 18.000 .000 \\
\hline 4 & Televisi & 8 unit & 14.000 .000 \\
\hline 5 & Meja kamar & 51 unit & 17.850 .000 \\
\hline 6 & $\begin{array}{l}\text { Tempat } \\
\text { Tidur }\end{array}$ & 59 unit & 25.075 .000 \\
\hline 7 & $\begin{array}{l}\text { Meja Kursi } \\
\text { Tamu }\end{array}$ & 1 set & 3.000 .000 \\
\hline 8 & $\begin{array}{l}\text { Meja } \\
\text { Receptionist }\end{array}$ & 1 unit & 4.000 .000 \\
\hline 9 & Meja Kerja & 6 unit & 5.700 .000 \\
\hline 10 & Kursi Kerja & 25 unit & 4.625 .000 \\
\hline 11 & $\begin{array}{l}\text { Kipas } \\
\text { Angin }\end{array}$ & 2 unit & 600.000 \\
\hline 12 & Almari & 5 unit & 7.000 .000 \\
\hline 13 & Telepon & 2 unit & 400.000 \\
\hline 54
\end{tabular}

Sumber: Hotel Blitar Indah (2017)

a. Penyusutan Aset Tetap

Hotel Blitar Indah belum melakukan perhitungan dan pencatatan penyusutan terhadap aset tetap yang dimiliki. Selama ini aset tetap hanya digunakan untuk operasional perusahaan tanpa memperhitungkan nilai yang disusutkan setiap tahun.

b. Pelepasan Aset Tetap 
Pada akhir penggunaan aset tetap Hotel Blitar Indah sudah melakukan pelepasan aset tetap dengan cara menghentikan peggunaan aset tetap dan memberikan pada karyawan tanpa melakukan perhitungan dan pencatatan pada pelepasan aset tetap.

3. Laporan Keuangan

Laporan Keuangan pada Hotel Blitar Indah terdiri dari Laporan Laba Rugi, Laporan Perubahan Ekuitas dan Neraca. Berikut penyajian laporan keuangan pada Hotel Blitar Indah tahun 2014, 2015 dan 2016:

a. Laporan Laba Rugi

Laporan Laba Rugi Hotel Blitar Indah menyajikan laporan pendapatan dan biaya yang dikeluarkan perusahaan setiap tahun. Sebelum perhitungan penyusutan aset tetap laba pada laporan laba rugi tahun 2014 menunjukkan nilai sebesar Rp 315.634.412,00, tahun 2015 sebesar Rp 323.312.682,00 dan tahun 2016 sebesar Rp 374.251.528,00.

b. Laporan Perubahan Ekuitas Laporan Perubahan Ekuitas Hotel Blitar Indah menyajikan Laporan perubahan modal awal suatu periode yang disebabkan oleh penambahan laba atau pengambilan prive pada setiap tahun. Modal Akhir yang disajikan pada tahun 2014 sebesar Rp 5.996.850.000,00, pada tahun 2015 sebesar Rp
5.970.162.682,00 dan pada tahun 2016 sebesar Rp 5.996.850,00.

c. Neraca

Neraca Hotel Blitar Indah menyajikan Aktiva yang berisi aset lancar dan aset tetap sementara Passiva menyajikan modal setiap tahun. Pada tahun 2014 aktiva dan passiva sebesar $\mathrm{Rp}$ 5.996.850.000,00. Sementara pada tahun 2015 aktiva dan passiva menunjukkan nilai sebesar $\mathrm{Rp}$ 5.970.162.682,00 dan tahun 2016 aktiva dan passive menunjukkan nilai sebesar Rp 6.344.414.210,00.

\section{PEMBAHASAN}

1. Perlakuan Akuntansi Aset Tetap Berdasarkan SAK ETAP

a. Perolehan Aset Tetap

1) Cara Perolehan Aset Tetap Berdasarkan SAK ETAP Bab 15 Cara perolehan aset tetap secara tunai, kredit dan pertukaran. Perolehan secara tunai bisa dengan pembelian atau dengan membuat sendiri aset tetap. Pada Hotel Blitar Indah aset tetap diperoleh dengan cara pembelian tunai untuk tanah dan peralatan. Sementara pada bangunan diperoleh dengan cara dibuat sendiri.

2) Harga Perolehan Aset Tetap Harga perolehan aset tetap sudah sesuai dengan SAK ETAP Bab 15 dengan menghitung semua biaya 
yang dikeluarkan untuk memperoleh aset tetap.

b. Penyusutan Aset Tetap Hotel Blitar Indah selama ini belum melakukan perlakuan akuntansi penyusutan aset tetap sehingga nilai aset tetap tidak sesuai dengan nilai sebenarnya. Metode yang dipilih untuk menghitung besar penyusutan adalah garis lurus. Hal ini dikarenakan metode garis lurus menghasilkan jumlah yang sama pada penyusutan setiap periode sehingga dinilai lebih mudah dalam melakukan perhitungan. Perhitungan penyusutan dengan cara Harga perolehan dikurangi dengan nilai sisa dibagi dengan masa manfaat. Berikut ini perlakuan akuntansi penyusutan aset tetap menggunakan metode Garis Lurus berdasarkan :

1) Tanah merupakan aset tetap yang tidak dilakukan perhitungan penyusutan. Hal ini dikarenakan tanah memiliki masa manfaat yang tidak terbatas sehingga dapat memberikan keuntungan jasa yang tidak terbatas.

2) Bangunan Hotel Blitar Indah pada tahun 2013 senilai

1.464.117.000,00

ditaksirkan memiliki masa manfaat 20 tahun dengan nilai sisa $10 \%$ dari harga perolehan aset tetap. Perhitungan penyusutan bangunan dimulai tahun
2014 dengan nilai sebesar Rp 65.885.265,00

3) Peralatan Hotel Blitar Indah terdiri dari Peralatan Kamar Hotel sebesar dan Peralatan Kantor. Peralatan ditaksirkan memiliki masa manfaat 5 tahun dan nilai sisa sebesar $10 \%$ dari harga perolehan. Berikut perhitungan penyusutan peralatan kamar hotel dan peralatan kantor Hotel Blitar Indah :

a) Perhitungan

Penyusutan Peralatan Kamar Hotel Blitar Indah sebagai berikut:
(1) Air Conditioner sebanyak 6 unit pada bulan Desember 2013 dengan harga perolehan AC sebesar Rp 18.000.000,00.
Perhitungan penyusutan AC dimulai tahun 2014 dengan nilai sebesar Rp 3.240.000,00.
(2) Televisi sebanyak 8 unit pada bulan Desember 2013 dengan harga perolehan Televisi sebesar $\quad \mathrm{Rp}$ 14.000.000,00. Perhitungan penyusutan televisi dimulai tahun 2014 dengan nilai sebesar Rp 2.520.000,00.
(3) Meja Kamar sebanyak 51 unit 


$$
\begin{aligned}
& \text { pada bulan } \\
& \text { Desember } 2012 \\
& \text { dengan harga } \\
& \text { perolehan meja } \\
& \text { kamar sebesar } \mathrm{Rp} \\
& \text { 17.850.000,00. } \\
& \text { Perhitungan } \\
& \text { penyusutan meja } \\
& \text { kamar dimulai } \\
& \text { tahun } 2013 \text { dengan } \\
& \text { nilai sebesar } \mathrm{Rp} \\
& \text { 3.213.000,00. }
\end{aligned}
$$

b) Perhitungan

Penyusutan Peralatan Kantor Hotel Blitar Indah sebagai berikut:

(1) Meja Kursi Tamu pada Desember 2011 sebanyak 1 set dengan harga perolehan sebesar Rp 3.000.000,00. Perhitungan penyusutan meja kursi tamu dimulai tahun 2012 dengan nilai sebesar $\mathrm{Rp}$ 540.000,00.

(2) Meja Receptionist sebanyak 1 unit pada Desember 2011 dengan harga perolehan sebesar Rp 4.000.000,00. Perhitungan penyusutan meja kursi tamu dimulai tahun 2012 dengan nilai sebesar $\mathrm{Rp}$ 720.000,00.

(3) Meja Kerja sebanyak 6 unit pada Desember 2011 dengan harga perolehan meja kerja sebesar Rp 5.700.000,00.

Perhitungan

penyusutan meja kerja dimulai tahun 2012 dengan nilai sebesar Rp 1.026.000,00.

(4) Kursi Kerja sebanyak 25 unit pada Desember 2011 dengan harga perolehan kursi kerja sebesar $\mathrm{Rp}$ 4.625.000,00.

Perhitungan

penyusutan kursi kerja dimulai tahun 2012 dengan nilai sebesar Rp 832.50,000.

(5) Kipas Angin sebanyak 2 unit pada tahun pada Desember 2011 dengan harga perolehan kipas angin sebesar $\mathrm{Rp}$ 600.000,00.

Perhitungan penyusutan kipas angin dimulai tahun 2012 dengan 
nilai sebesar $\mathrm{Rp}$ $108.000,00$.

(6) Almari sebanyak 5 unit pada Desember 2011 dengan harga perolehan almari sebesar $\mathrm{Rp}$ 7.000.000,00.

Perhitungan penyusutan almari dimulai tahun 2012 dengan nilai sebesar Rp 1.260.000,00.

(7) Telepon sebanyak 2 unit pada Desember 2011 dengan harga perolehan telepon sebesar $\quad \mathrm{Rp}$ 400.000,00.

Perhitungan penyusutan telepon dimulai tahun 2012 dengan nilai sebesar $\mathrm{Rp} 72.000,00$.

Berdasarkan perhitungan diatas penyusutan peralatan kamar hotel dan peralatan kantor Hotel Blitar Indah pada tahun 2014 sampai dengan tahun 2016 sebesar $\mathrm{Rp}$ 18.045.000,00.

3. Pelepasan Aset Tetap

Berdasarkan SAK ETAP Bab 15 Entitas harus menghentikan-pengakuan

aset tetap pada saat dilepaskan atau ketika tidak ada manfaat ekonomi masa depan yang diekspektasikan dari penggunaan atau pelepasannya. Pelepasan aset tetap pada Hotel Blitar Indah dengan memberikan aset tetap berupa peralatan pada karyawan setelah digunakan selama 5 tahun tanpa melakukan pencatatan pelepasan aset tetap, sehingga bisa dikatakan bahwa perlakuan akuntansi pelepasan aset tetap Hotel Blitar Indah belum sesuai SAK ETAP. Berdasarkan pelepasan aset yang dilakukan hotel Blitar Indah termasuk dalam pelepasan aset tetap dengan metode penghentian aset tetap yaitu hanya dengan menghentikan penggunaan aset tetap tanpa melakukan pertukaran aset tetap atau penjualan aset tetap. Berikut perhitungan penghentian aset tetap berupa peralatan berdasarkan SAK ETAP:

Peralatan ditaksir memiliki masa manfaat selama 5 tahun. Pada saat penggunaan peralatan terjadi penyusutan sebesar $\mathrm{Rp}$ 90.225.000,00 dengan nilai sisa sebesar $\mathrm{Rp}$ $10,025,000,00$ sehingga nilai sisa peralatan dianggap sebagai kerugian penghentian peralatan. Peralatan ditaksir memiliki masa manfaat selama 5 tahun sehingga jika perhitungan penyusutan dimulai tahun 2014 maka masa manfaat akan habis pada tahun 2018. Penghentian peralatan dilakukan pada akhir periode tahun 2018. Jurnal untuk mencatat penghentian peralatan sebagai berikut:

Akumulasi Penyusutan Peralatan Rp 90.225.000,00 


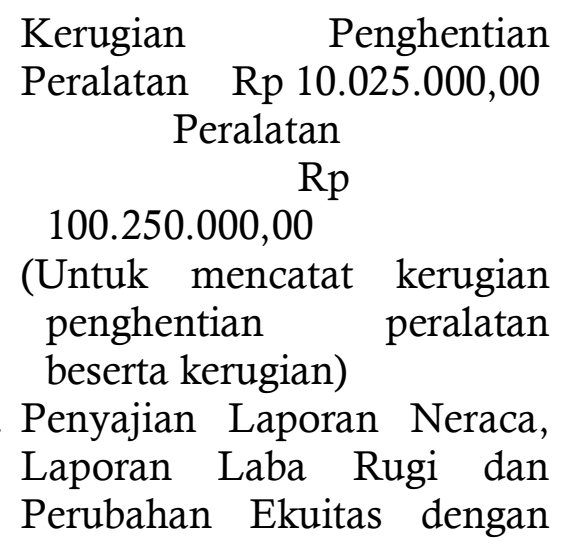

perlakuan akuntansi aset tetap berdasarkan SAK ETAP.

a. Laporan Laba Rugi Berikut penyajian Laporan Laba Rugi setelah perhitungan penyusutan aset tetap berdasarkan SAK ETAP pada tabel 2 sampai

3:

Tabel 2

Laporan Laba Rugi Hotel Blitar Indah Tahun 2014

\begin{tabular}{|c|c|}
\hline $\begin{array}{c}\text { HOTEL BLITAR INDAH } \\
\text { LAPORAN LABA RUGI } \\
\text { 31 Desember } 2014 \\
\end{array}$ & \\
\hline \multicolumn{2}{|l|}{ PENDAPATAN } \\
\hline Pendapatan kamar & $785,330,000$ \\
\hline Jumlah Pendapatan & $785,330,000$ \\
\hline \multicolumn{2}{|l|}{ BIAYA } \\
\hline Biaya Administrasi & $8,000,000$ \\
\hline Biaya Operasional Dapur & $34,230,000$ \\
\hline Biaya Operasional Kebersihan & $36,200,000$ \\
\hline Biaya Perlengkapan Kantor & $6,300,000$ \\
\hline Biaya Perjalanan Dinas & $38,000,000$ \\
\hline Gaji & $111,779,982$ \\
\hline Seragam Karyawan & $6,200,000$ \\
\hline Pajak Bumi Bangunan & $11,015,306$ \\
\hline Biaya Pemeliharaan & $79,523,000$ \\
\hline Biaya Asuransi & $14,566,000$ \\
\hline Listrik & $57,260,000$ \\
\hline Telepon & $4,768,000$ \\
\hline Biaya Operasional Kamar & $47,500,000$ \\
\hline Biaya Lain-Lain & $6,500,000$ \\
\hline Penyusutan & $83,930,265$ \\
\hline Jumlah Biaya & $545,772,553$ \\
\hline LABA SEBELUM PAJAK & $239,557,447$ \\
\hline
\end{tabular}


PPH

LABA BERSIH

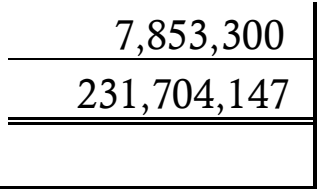

Sumber : Hotel Blitar Indah (data diolah)

Tabel 3

Laporan Laba Rugi Hotel Blitar Indah Tahun 2015

\begin{tabular}{|cr|}
\hline \multicolumn{2}{|c|}{ HOTEL BLITAR INDAH } \\
LAPORAN LABA RUGI \\
31 Desember 2015 \\
\hline PENDAPATAN & \\
Pendapatan kamar & $806,360,000$ \\
\cline { 2 - 2 } Jumlah Pendapatan & $806,360,000$ \\
BIAYA & \\
Biaya Administrasi & $8,550,000$ \\
Biaya Operasional Dapur & $34,520,000$ \\
Biaya Operasional Kebersihan & $37,200,000$ \\
Biaya Perlengkapan Kantor & $6,925,000$ \\
Biaya Perjalanan Dinas & $40,000,000$ \\
Gaji & $114,765,000$ \\
Seragam Karyawan & $6,800,000$ \\
Pajak Bumi Bangunan & $11,015,306$ \\
Biaya Pemeliharaan & $80,880,000$ \\
Biaya Asuransi & $15,272,412$ \\
Listrik & $59,240,000$ \\
Telepon & $4,786,000$ \\
Biaya Operasional Kamar & $48,230,000$ \\
Biaya Lain-Lain & $6,800,000$ \\
Penyusutan & $83,930,265$ \\
Jumlah Biaya & $558,913,983$ \\
LABA SEBELUM PAJAK & \\
PPH & $247,446,017$ \\
\hline LABA BERSIH & $8,063,600$ \\
& $239,382,417$ \\
\hline
\end{tabular}

Sumber : Hotel Blitar Indah (data diolah)

Tabel 4

Laporan Laba Rugi Hotel Blitar Indah Tahun 2016 


\begin{tabular}{|c|c|}
\hline \multicolumn{2}{|c|}{$\begin{array}{c}\text { HOTEL BLITAR INDAH } \\
\text { LAPORAN LABA RUGI } \\
\text { 31 Desember } 2016\end{array}$} \\
\hline \multicolumn{2}{|c|}{ PENDAPATAN } \\
\hline Pendapatan kamar & $894,833,000$ \\
\hline Jumlah Pendapatan & $894,833,000$ \\
\hline \multicolumn{2}{|l|}{ BIAYA } \\
\hline Biaya Administrasi & $9,300,000$ \\
\hline Biaya Operasional Dapur & $35,230,000$ \\
\hline Biaya Operasional Kebersihan & $38,000,000$ \\
\hline Biaya Perlengkapan Kantor & $7,634,000$ \\
\hline Biaya Perjalanan Dinas & $45,200,000$ \\
\hline Gaji & $130,050,000$ \\
\hline Seragam Karyawan & $7,100,000$ \\
\hline Pajak Bumi Bangunan & $11,015,306$ \\
\hline Biaya Pemeliharaan & $86,645,000$ \\
\hline Biaya Asuransi & $18,104,836$ \\
\hline Listrik & $62,580,000$ \\
\hline Telepon & $4,804,000$ \\
\hline Biaya Operasional Kamar & $48,770,000$ \\
\hline Biaya Lain-Lain & $7,200,000$ \\
\hline Penyusutan & $83,930,265$ \\
\hline Jumlah Biaya & $595,563,407$ \\
\hline LABA SEBELUM PAJAK & $299,269,593$ \\
\hline PPH & $8,948,330$ \\
\hline LABA BERSIH & $290,321,263$ \\
\hline
\end{tabular}


b. Laporan Perubahan Ekuitas

Berikut penyajian Laporan Perubahan Ekuitas setelah perhitungan penyusutan aset tetap berdasarkan SAK ETAP:

Tabel 5

Laporan Perubahan Ekuitas Hotel Blitar Indah Tahun 2014

\begin{tabular}{|l|}
\hline \multicolumn{1}{|c|}{\begin{tabular}{c}
\multicolumn{1}{|c|}{ HOTEL BLITAR INDAH } \\
LAPORAN PERUBAHAN \\
EKUITAS \\
31 Desember 2014 \\
(dalam rupiah)
\end{tabular}} \\
\hline $\begin{array}{l}\text { MODAL } \\
\text { AWAL }\end{array}$ \\
$\begin{array}{l}\text { LABA } \\
\text { BERSIH }\end{array}$ \\
$\begin{array}{l}\text { MODAL } \\
\text { AKHIR }\end{array}$ \\
\hline Sumber: Hotel Blitar Indah (data diolah)
\end{tabular}

Tabel 6

Laporan Perubahan Ekuitas Hotel Blitar Indah Tahun 2015

\begin{tabular}{|c|c|}
\hline \multicolumn{2}{|c|}{$\begin{array}{c}\text { HOTEL BLITAR INDAH } \\
\text { LAPORAN PERUBAHAN EKUITAS } \\
31 \text { Desember 2014 } \\
\text { (dalam rupiah) }\end{array}$} \\
\hline MODAL AWAL & $5,912,919,735$ \\
\hline LABA BERSIH & $239,382,417$ \\
\hline PRIVE & $(350,000,000)$ \\
\hline MODAL AKHIR & $5,802,302,152$ \\
\hline
\end{tabular}

Sumber : Hotel Blitar Indah (data diolah) 
Tabel 7

Laporan Perubahan Ekuitas Hotel Blitar Indah Tahun 2016

\begin{tabular}{|l|}
\hline \multicolumn{1}{|c|}{$\begin{array}{c}\text { HOTEL BLITAR INDAH } \\
\text { LAPORAN PERUBAHAN } \\
\text { EKUITAS } \\
\text { 31 Desember 2014 } \\
\text { (dalam rupiah) }\end{array}$} \\
\hline MODAL AWAL \\
LABA BERSIH \\
MODAL \\
AKHIR \\
\hline
\end{tabular}

Sumber : Hotel Blitar Indah (data diolah)

c. Neraca

Berikut penyajian Neraca setelah perlakuan akuntansi penyusutan aset tetap pada tabel $5 \mathrm{~s} / \mathrm{d} 8$ :

Tabel 8

Neraca Hotel Blitar Indah Tahun 2014

\begin{tabular}{|c|c|c|c|}
\hline \multicolumn{4}{|c|}{$\begin{array}{c}\text { HOTEL BLITAR INDAH } \\
\text { NERACA } \\
\text { 31 Desember } 2014 \\
\end{array}$} \\
\hline AK & TIVA & & SSIVA \\
\hline $\begin{array}{l}\text { AKTIVA } \\
\text { LANCAR }\end{array}$ & & MODAL & $5,912,919,735$ \\
\hline Kas & $529,252,000$ & & \\
\hline $\begin{array}{l}\text { Jumlah Aset } \\
\text { Lancar }\end{array}$ & $529,252,000$ & & \\
\hline $\begin{array}{l}\text { ASET } \\
\text { TETAP }\end{array}$ & & & \\
\hline Tanah & $3,903,231,000$ & & \\
\hline $\begin{array}{l}\text { Bangunan } \\
\text { Akumulasi } \\
\text { Penyusutan } \\
\text { Bangunan }\end{array}$ & $1,464,117,000$ & & \\
\hline
\end{tabular}




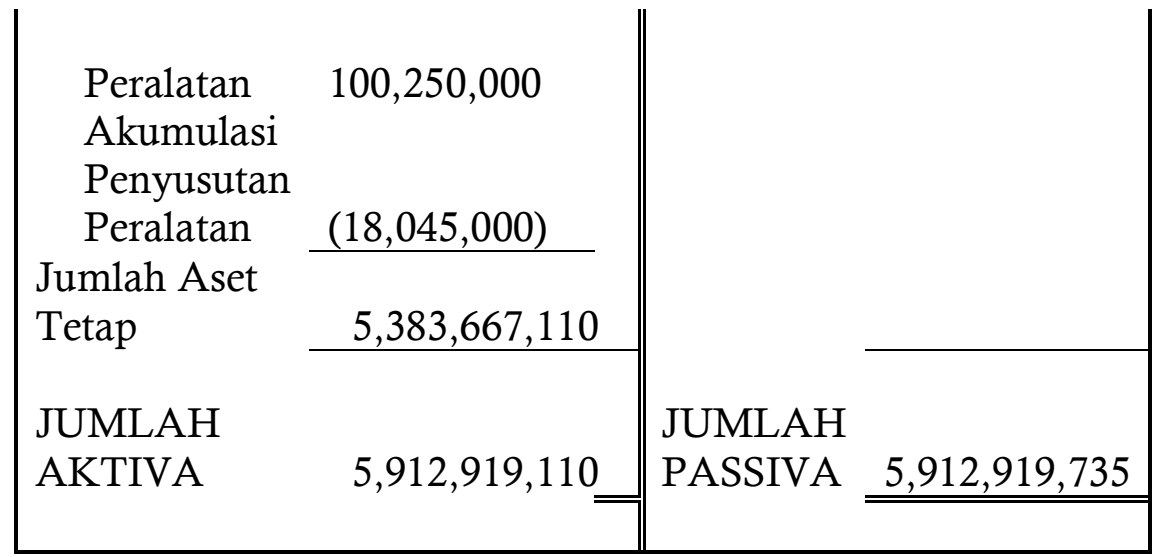

Sumber : Hotel Blitar Indah (data diolah)

Tabel 9

Neraca Hotel Blitar Indah Tahun 2015

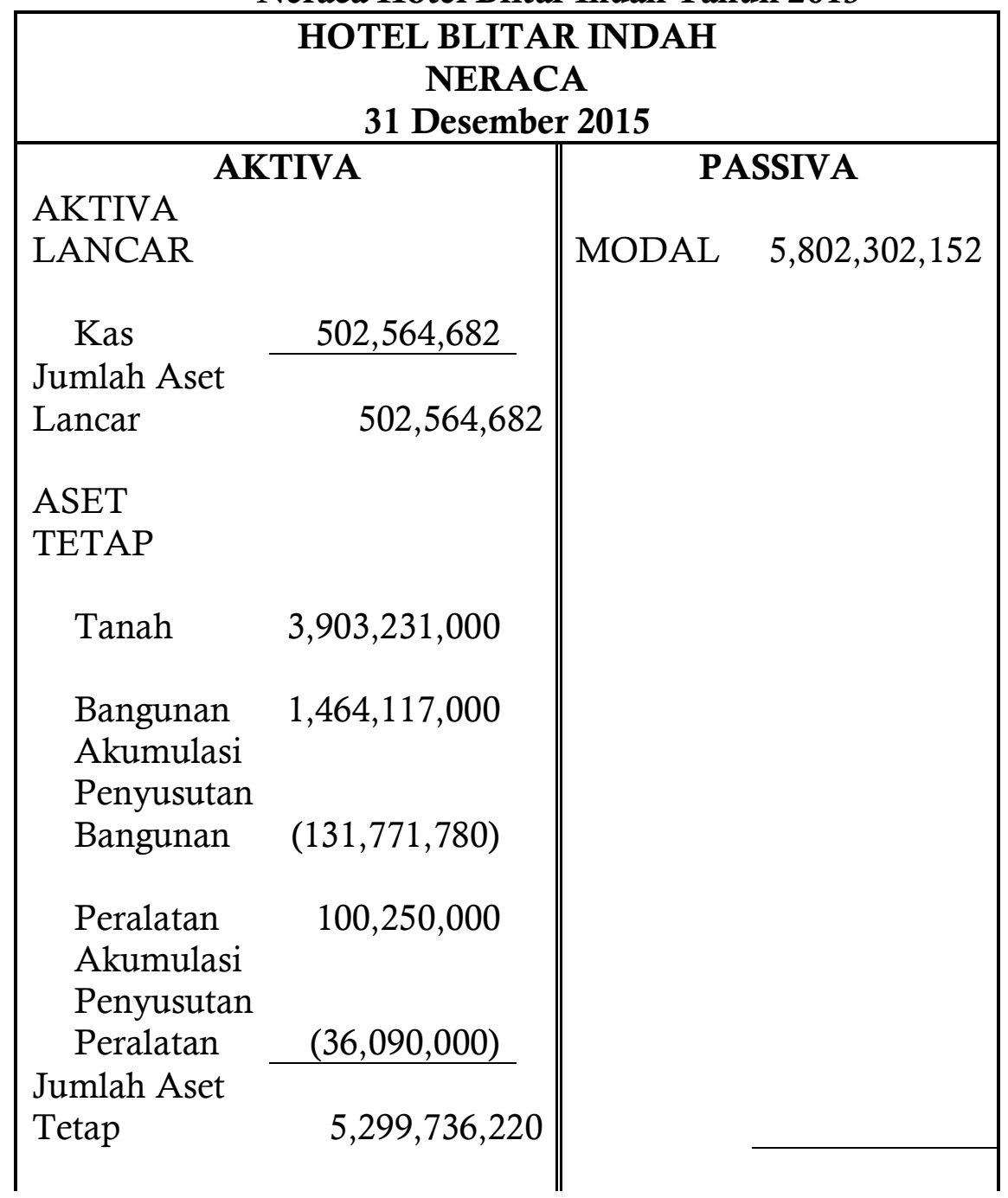




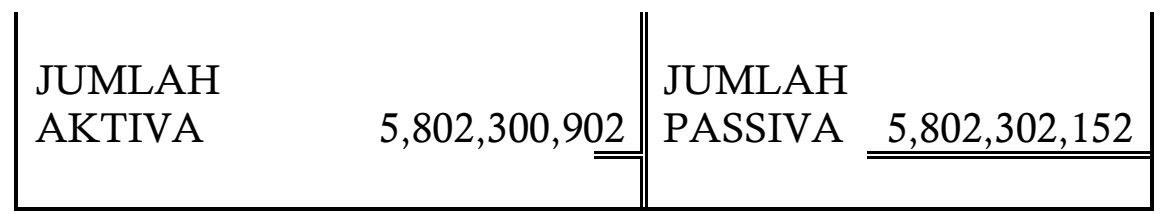

Sumber : Hotel Blitar Indah (data diolah)

Tabel 10

Neraca Hotel Blitar Indah Tahun 2016

HOTEL BLITAR INDAH

NERACA

31 Desember 2016

\begin{tabular}{|c|c|c|c|}
\hline \multicolumn{2}{|c|}{ AKTIVA } & \multicolumn{2}{|c|}{ PASSIVA } \\
\hline LANCAR & & MODAL & $6,092,623,415$ \\
\hline Kas & $876,816,210$ & & \\
\hline Jumlah Aset & & & \\
\hline Lancar & $876,816,210$ & & \\
\hline \multicolumn{4}{|l|}{ ASET } \\
\hline \multicolumn{4}{|l|}{ TETAP } \\
\hline Tanah & $3,903,231,000$ & & \\
\hline Bangunan & $1,464,117,000$ & & \\
\hline Akumulasi & & & \\
\hline Penyusutan & & & \\
\hline Bangunan & $(197,657,670)$ & & \\
\hline Peralatan & $100,250,000$ & & \\
\hline Akumulasi & & & \\
\hline Penyusutan & & & \\
\hline Peralatan & $(54,135,000)$ & & \\
\hline Jumlah Aset & & & \\
\hline Tetap & $5,215,805,330$ & & \\
\hline JUMLAH & & JUMLAH & \\
\hline AKTIVA & $6,092,621,540$ & PASSIVA & $6,092,623,415$ \\
\hline
\end{tabular}

Sumber : Hotel Blitar Indah (data diolah) 
5. Kesimpulan perbandingan perlakuan akuntansi aset tetap terhadap laporan keuangan pada Hotel Blitar Indah dan perlakuan akuntansi aset tetap terhadap laporan keuangan berdasarkan SAK-ETAP :

1) Perolehan aset tetap

a. Cara Perolehan dan Harga Pertolehan Aset Tetap Hotel Blitar Indah sudah diperhitungkan sesuai dengan SAK ETAP dengan metode pembelian tunai pada peralatan dan tanah serta bangunan yang dibuat sendiri.

b. Penyusutan aset tetap Hotel Blitar Indah belum sesuai dengan SAK ETAP karena belum adanya perhitungan dan pencatatan penyusutan aset tetap. Hal ini mengakibatkan laba yang dihasilkan menjadi lebih besar karena belum ada biaya penyusutan yang dikeluarkan.

2) Penghentian aset tetap Hotel Blitar Indah belum sesuai SAK ETAP karena hanya melakukan penghentian aset tetap berupa peralatan tanpa melakukan perhitungan dan pencatatan penghentian peralatan. $\mathrm{Hal}$ ini mengakibatkan pada data aset tetap masih terdapat aset tetap yang sebenarnya sudah tidak digunakan dalam kegiatan operasional.

3) Penyajian Laporan Keuangan Blitar Indah belum menunjukkan nilai yang sebenarnya. Pada Laporan Laba Rugi setelah perhitungan aset tetap berdasarkan SAK ETAP laba yang dihasilkan lebih kecil daripada Laporan Laba Rugi yang dibuat oleh pihak Hotel. Perbedaan tersebut disebabkan oleh Laporan Laba Rugi pihak hotel belum menyajikan perhitungan penyusutan aset tetap. Sehingga berpengarub pada pencatatan Neraca dan Laporan Perubahan Ekuitas.

\section{KESIMPULAN DAN SARAN Kesimpulan}

Berdasarkan hasil analisa dan pembahasan yang dilakukan pada Hotel Blitar Indah, penulis dapat menarik kesimpulan atas perlakuan akuntansi aset tetap terhadap laporan keuangan berdasarkan SAK ETAP sebagai berikut:

1. Perlakuan akuntansi aset tetap pada Hotel Blitar Indah belum sepenuhnya sesuai dengan SAK ETAP karena hanya pada perolehan aset tetap yang sudah dilakukan perhitungan dan pencatatan sesuai dengan SAK ETAP.

2. Penghentian aset tetap Hotel Blitar Indah belum sesuai 
dengan SAK ETAP. Hotel Blitar Indah hanya menghentikan penggunaan tanpa melakukan perhitungan dan pencatatan. Hal ini mengakibatkan nilai aset tetap lebih besar dari nilai sebenarnya karena aset tetap yang sudah tidak digunakan dalam kegiatan operasional masih tercantum pada data aset tetap.

3. Perlakuan akuntansi pada aset tetap yang belum sesuai tersebut mengakibatkan penyajian Laporan Keuangannya juga belum sesuai dengan kondisi perusahaan yang sebenarnya.

4. Setelah dilakukan perhitungan penyusutan dan pelepasan aset tetap, data aset yang dihasilkan lebih akurat karena aset tetap yang sudah digunakan telah dilakukan penyusutan dan asset tetap yang tidak digunakan dalam kegiatan operasional sudah diakui penghentiannya.

5. Pada Laporan Laba Rugi setelah perhitungan aset tetap berdasarkan SAK ETAP, laba yang dihasilkan lebih kecil daripada Laporan Laba Rugi yang dibuat oleh pihak Hotel. Perbedaan tersebut disebabkan oleh Laporan Laba Rugi pihak hotel belum menyajikan perhitungan penyusutan aset tetap. Sementara pada Neraca yang dibuat pihak hotel nilai aset tetap terlihat lebih besar daripada Netaca yang setelah perhitungan aset tetap berdasarkan SAK ETAP. Hal ini dikarenakan belum adanya pencatatan pada akumulasi penyusutan aset tetap pada
Neraca yang dibuat oleh pihak Hotel.

\section{Saran}

Berdasarkan kesimpulan yang diperoleh, maka penulis memberikan saran mengenai perlakuan akuntansi aset tetap terhadap laporan keuangan berdasarkan SAK ETAP sebagai berikut:

1. Perlu adanya perhitungan dan pencatatan penyusutan aset tetap sehingga biaya yang dikeluarkan lebih akurat. Pada perhitungan penyusutan aset tetap penulis menyarankan menggunakan Metode Garis Lurus. Hal ini dikarenakan metode garis lurus mengalokasikan penyusutan yang sama besar pada setiap periode sehingga dinilai lebih mudah digunakan pada perusahaan kecil.

2. Perlu adanya penghentian aset tetap, aset tetap yang sudah tidak digunakan dalam operasional perusahaan akan dihapuskan dari laporan keuangan sehingga aset tetap yang disajikan pada laporan keuangan sesuai dengan kondisi aset tetap yang sebenarnya.

3. Pada penyusunan laporan keuangan disajikan nilai aset tetap setelah perhitungan penyusutan dan pelepasan aset tetap. Pada laporan laba rugi akan nampak beban penyusutan yang menambah biaya yang dikeluarkan setiap periode, sehingga laba yang dihasilkan lebih akurat. Pada laporan perubahan ekuitas, laba yang disajikan sesuai dengan nilai 
pada laporan laba rugi. Sementara pada neraca, akan nampak nilai aset yang disertai akumulasi penyusutan aset tetap.

\section{DAFTAR RUJUKAN}

Bahri, Syaiful. 2016. Pengantar Akuntansi Berdasarkan SAK ETAP dan IFRS.Andi. Yogyakarta.

Baridwan, Zaki. 2008. Intermediate Accounting. Edisi Kedelapan. BPFE. Yogyakarta.

Greunning, Henrie Van, et al. 2013. International Financial Reporting Standart. Edisi 6. Salemba Empat. Jakarta.

Ikatan Akuntan Indonesia. 2009. Standar Akuntansi Keuangan Entitas Tanpa Akuntabilitas Publik. Dewan Standar Akuntansi Keuangan. Jakarta. Jusup, A1.Haryono, et al. 2011. Dasar - Dasar Akuntansi. Jilid 2. Edisi Ketujuh. STIE YKPN. Yogyakarta.

Kartikahadi, Hans, et al. 2012. Akuntansi Keuangan Menengah Berdasarkan SAK Berbasis IFRS. Buku 1. Salemba Empat. Jakarta.
Kristiana, Yuyus. 2014. Analisis Perlakuan Akuntansi Aset Tetap Brwujud dan Penerapan Metode Depresiasi untuk Pengungkapan Laporan Keuangan Pada CV. Tirtonadi Blitar.Skripsi. Program Studi Akuntansi STIE Kesuma Negara. Blitar.

Martani, Dwi, et al. 2012. Akuntansi Keuangan Menengah Berbasis PSAK. Buku 1. Salemba Empat. Jakarta.

Purba, Marisi P. 2013. Akuntansi Keuangan Aset Tetap dan Aset Tak Berwujud. Edisi Pertama. Graha Ilmu. Yogyakarta.

Reeve, James.R, et al. 2013. Pengantar Akuntansi Adaptasi Indonesia. Buku 2. Salemba Empat. Jakarta.

Wijaya, Tri Yanti et al. 2014. AnalisiS Perlakuan Akuntansi Atas Aset Tetap Terhadap Laporan Keuangan Berdasarkan SAK ETAP no.15. Journal Riset Mahasiswa. Universitas Kanjuruhan. Malang.

Wulansari, Eko Noviana. 2013. Penerapan Akuntansi Aktiva Tetap Pada Rumah Sakit Bersalin An-Nisaa' Wlingi. Skripsi. Program Studi Akuntansi STIE Kesuma Negara. Blitar. 